\title{
STUDI EVALUASI PROGRAM EMPAT BULAN LULUS IQRA JILID 1-6 DI SD MUHAMMADIYAH AMBARKETAWANG 3 YOGYAKARTA
}

\author{
Anik Oktavia Gesang \\ Nurul Hidayati Rofiah \\ PGSD FKIP Universitas Ahmad Dahlan \\ anikoktav@gmail.com
}

\begin{abstract}
The research aims to find out the evaluation result of the implementation of four months program of Iqra pass, to know the supporting and inhibiting factors, and to know the follow up plan of the implementation of the four month program pass Iqra. The research used is evaluative research with descriptive data analysis method. Research subjects are principal, teacher coordinator of program implementer. The research was conducted at SD Muhammadiyah Ambarketawang 3 Yogyakarta by using interview, observation, and documentation. Validity of data using credibility test that is using triangulation of source and technique.

The results showed the four-month program Iqra graduated successfully and performed quite well. Supporting factors in the implementation of the program include student activeness, contributions of principals, teachers, learning facilities are quite good, as well as sufficient program funds. As for the inhibiting factors is the lack of parental participation and differences in ability of each child. Based on these results, the fourmonth Iqra program can be continued by performing several improvements such as in terms of infrastructure, the use of Iqra teaching guidance, and improvements related to the contribution of parents to the program.
\end{abstract}

Keywords: evaluation, iqra program, primary school

\begin{abstract}
ABSTRAK
Penelitian bertujuan untuk mengetahui hasil evaluasi pelaksanaan program empat bulan lulus Iqra, mengetahui faktor pendukung dan penghambat, serta untuk mengetahui rencana tindak lanjut pelaksanaan program empat bulan lulus Iqra. Penelitian yang digunakan merupakan penelitian evaluatif dengan metode analisis data deskriptif. Subjek penelitian yaitu kepala sekolah, guru koordinator pelaksana program. Penelitian dilaksanakan di SD Muhammadiyah Ambarketawang 3 Yogyakarta dengan menggunakan wawancara, observasi, dan dokumentasi. Keabsahan data menggunakan uji kredibilitas yaitu menggunakan trianggulasi sumber dan teknik.

Hasil penelitian menunjukkan program empat bulan lulus Iqra berhasil dan terlaksana dengan cukup baik. Faktor pedukung dalam pelaksanaan program meliputi keaktifan siswa, kontribusi kepala sekolah, guru, fasilitas pembelajaran yang cukup baik, serta dana program yang mencukupi. Sedangkan untuk faktor penghambat adalah kurangnya partisipasi orang tua dan perbedaan kemampuan dari masing-masing anak. Berdasarkan hasil tersebut maka program empat bulan lulus Iqra dapat tetap dilanjutkan dengan
\end{abstract}


melakukan beberapa perbaikan seperti, dari segi sarana prasarana, penggunaan pedoman pengajaran Iqra, serta perbaikan terkait kontribusi orang tua terhadap program.

Kata kunci: evaluasi, program iqra, sekolah dasar

\section{PENDAHULUAN}

Islam adalah agama yang sangat memperhatikan semua aspek kegiatan manusia selama hidup di dunia. Al Quran berkaitan dengan dua hal, yaitu dunia dan akhirat, masalah dunia termasuk bidang ekonomi, sosial, politik, hubungan antar umat, dan lain sebagainya (Nata,2010). Menjaga dan memurnikan Al Quran sangat penting dilakukan oleh setiap umat muslim. Usaha menjaga kemurnian Al Quran di Indonesia salah satunya melalui sekolah hafal Al Quran, taman pendidikan Al Quran, perguruan tinggi Al Quran dan lain sebagainya (Zainal dan Bahar, 2013),. Melalui beberapa cara tersebut diharapkkan kemurnian Al Quran akan tetap terjaga dan semakin menumbuhkan kecintaan individu terhadap Al Quran.

Membaca dan memahami Al Quran sebagai pedoman hidup tentu tidak dapat dilakukan secara instan. Pendidikan AI-Qur`an perlu diajarkan sejak dini. Sebuah Hadis, anak-anak harus selalu diajarkan membaca Iqra dengan metode pengulangan atau pembisaan (Huda, 2009). Metode pengulangan yang digunakan selaras dengan pendapat yang dikemukakan oleh Muhaimin (2010), ajaran agama yang diberikan kepada anak bukan pemberian pengertian yang muluk-muluk, tetapi mengarah pada peragaan hidup riil melalui latihan dan pembisaan seperti membaca Al Quran, latihan salat, doa, dan lain sebaginya.

SD Muhammadiyah Ambarketawang 3 menerapkan sebuah program baru terkait pengajaran Al Quran. Program yang dilaksanakan disebut program empat bulan lulus Iqra. Kegiatan yang mendukung untuk menanamkan budaya lancar membaca Al Quran dan salah satu program unggulan yang dilakukan rutin dengan metode drill/ pembiasaan. Penyelenggaraan program empat bulan lulus Iqra sebagai salah sau bentuk realisasi dari visi, misi, dan tujuan yang dimiliki oleh SD Muhammadiyah Ambarketawang 3 Yogyakarta. Program tersebut dilaksanakan terhitung mulai semester ganjil tahun ajaran 2016/2017. Sasaran program empat bulan lulus Iqra ini hanya dilaksanakan untuk siswa kelas 1. Angkatan pertama semester ganjil tahun ajaran 2016/2017 tercatat sebanyak 68 siswa kelas 1 yang mengikuti kegiatan, sedangkan untuk angkatan kedua semester ganjil tahun ajaran 2016/2017 terdata sebanyak 71 siswa.

Setelah dua periode penyelenggaraan program empat bulan lulus Iqra, sampai saat ini sekolah belum pernah melakukan evaluasi terkait program tersebut. Evaluasi program dilaksanakan untuk, memperbaiki, menyempurnakan, meningkatkan, dan mengambil keputusan tentang suatu program, dengan alternatif, diberhentikan, dilanjutkan, atau diperbaiki (Yusuf, 2015). Oleh karena itu, peneliti bermaksud mengadakan sebuah studi evaluasi program empat bulan lulus Iqra di SD Muhammadiyah Ambarketawang 3 Yogyakarta untuk mengetahui keberhasilan program, kendala yang ditemukan, dan alternatif solusi yang dapat peneliti sampaikan.

Tujuan yang diharapkan dalam penelitian ini adalah: mengetahui hasil evaluasi pelaksanaan program empat bulan lulus Iqra di SD Muhammadiyah Ambarketawang 3 Yogyakarta, mengetahui faktor pendukung dan penghambat keberhasilan program empat bulan lulus Iqra di SD Muhammadiyah Ambarketawang 3 Yogyakarta, serta dapat mengetahui rencana tindak lanjut pelaksanaan program empat bulan lulus Iqra di SD Muhammadiyah Ambarketawang 3 Yogyakarta.

Metode pengajaran Al Quran telah banyak diterapkan. Metode pengajaran Al Quran terus diinovasi sesuai perkembangan zaman. Berbagai jenis metode sudah banyak 
berkembang, mulai dari metode klasik dengan menghafal sampai metode Al Quran berbasis teknologi. Apabila diklasifikasikan terdapat empat jenis metode pengajaran Al Quran. Klasifikasikan jenis metode pengajaran Al Quran sebagai berikut: Athariqat uttarkibiyyah (Metode Sintetik), Thariqat Shautiyyah (Metode Bunyi), Thariqat Musyafahah (Metode Meniru), Thariqat Jaami'ah (Metode Campuran) (Sophya dan Mujab, 2014).

Pemilihan metode pembelajaran oleh guru sangat penting dilakukan, termasuk metode pada proses pembelajaran Al Quran. Guru harus mampu memilih metode pembelajaran yang tepat agar pembelajaran Al Quran menjadi efektif, efisien, dan menyenangkan bagi siswa. Terdapat beberapa macam metode pembelajaran Al Quran, antara lain: Metode Baghdadiyah, Metode Qiro 'ati, Metode Ummi, Metode Jibril, Metode Al-Barqi, Metode Tilawati, Metode Yanbu`a.

Budiyanto (1995), buku Iqra disusun oleh Ustadz As`ad Humam sekitar tahun 19831988. Beliau lahir di Kotagede, Yogyakarta tahun 1933. Pada awalnya beliau mengajarkan membaca Al Quran untuk anak-anak di lingkungannya menggunakan pola pengajaran lama, yaitu dengan kaidah Baghdadiyah atau yang lebih dikenal dengan istilah turutan. Cara tersebut ternyata tidak memuaskan hati beliau, karena dinilai terlalu lambat dalam mengantarkan anak bisa membaca Al Quran, yaitu setelah belajar selama 2-3 tahun. Pada tahun 1950, beliau memodifikasi kaidah Baghdadiyah, yaitu tidak lagi mengeja dengan pola lama tetapi dicoba dengan pola baru dengan cara mencari padanan huruf-huruf hijaiyyah dengan huruf-huruf latin. Misalnya diajarkan tanda-tanda baca fathah sama dengan $a$, kasrah sama dengan $I$, dhomah sama dengan $u$, dan sebagainya.

Pada tahun 1970, beliau mendapatkan buku Qiro `ati yang disusun oleh ustaz Dahlan Salim. Ustadz As`ad Humam bertemu dengan sejumlah anak-anak muda pengajar Al Quran yang terhimpun dalam Team Tadarus Angkatan Muda Masjid dan Musholla Yogyakarta (Team Tadarus AMM), dengan pusat kesekretariatan di musholla Baiturrahman Selokraman Kotagede Yogyakarta. Buku Qiro`ati yang telah didapat oleh Ustadz As`ad Humam kemudian disempurnakan bersama dengan Team Tadarus AMM menjadi buku Iqra yang saat ini dijadikan sebagai metode belajar membaca Al Quran.

Budiyanto (1995), buku Iqra disusun dalam buku-buku kecil dengan ukuran seperempat folio dan terbagi dalam enam jilid. Masing-masing jilid memiliki 43 halaman, dengan warna sampul masing-masing jilid yang berbeda. Jilid 1 berwarna merah, jilid 2 berwarna hijau, jilid 3 berwarna biru muda, jilid 4 berwarna kuning kunyit, jilid 5 berwarna ungu, dan jilid 6 berwarna coklat.

Jilid-jilid tersebut disusun berdasarkan urutan dan tertib materi yang harus dilalui secara bertahap oleh masing-masing anak. Jilid 2 adalah kelanjutan jilid 1, jilid 3 adalah kelanjutan jilid 2, demikian seterusnya sampai jilid 6. Bagi anak yang telah menyelesaikan jilid 6, bila mengerjakan sesuai dengan petunjuk, dapat dipastikan bahwa anak telah mampu membaca Al Quran dengan benar. Budiyanto (1995), buku Iqra disusun berdasarkan prinsip:

a) At-thoriqoh as-shoutiyah.

b) At-thoriqoh bi-taddaruj.

c) At-thoriqoh bi-riyadhotil athfal.

d) At-tawasufilmakho shidla fil alats.

e) At-thariyukoh bimura 'atil isti'da diwathabi`.

Kelebihan dan kelemahan dalam pembelajarn Al Quran dengan penggunaan metode Iqra adalah siswa lebih cepat dapat membaca. Sedangkan kelemahannya adalah siswa kurang mengenal nama-nama huruf hijaiyyah asli, serta nama-nama tanda baca Al Quran dan bentuk-bentuk penulisan Al Quran. 
Evaluasi program pembelajaran Iqra didefinisikan sebagai proses mengetahui pencapaian dan mencari informasi terkait pelaksanaan program Iqra sehingga dapat dianalisis dan mempermudah melakukan pengambilan keputusan tindak lanjut program pembelajaran Iqra. Suharsimi, (2009) beberapa model evaluasi ahli yang banyak digunakan dalam penelitian yaitu: (a) Goal oriented evaluation model, dikembangkan oleh Tyler; (b) Goal free evaluation model, dikembangkan oleh Scriven; (c) Formatif summative evaluation model, dikembangkan oleh Michael Scriven; (d) Countenance evaluation model, dikembangkan oleh Stake; (e) Responsive evaluation model, dikembangkan oleh Stake; (f) CSE-UNCLA evaluation model; (g) CIPP evaluation model, dikembangkan oleh Stufflebeam; (h) Discrepancy model, dikembangkan oleh Provus.

Berdasarkan beberapa model evaluasi di atas, peneliti memilih model CIPP (Context, Input, Process, and Product) oleh Stufflebeam untuk mengevaluasi program empat bulan lulus Iqra di SD Muhammadiyah Ambarketawang 3 Yogyakarta. Model CIPP dipilih dalam melaksanakan proses evaluasi karena model tersebut lebih komperhensif dan mudah diterapkan dibandingkan dengan model yang lain. Selain itu model CIPP juga merupakan model yang paling banyak dikenal dan diterapkan oleh para evaluator.

\section{METODE PENELITIAN}

Jenis penelitian yang digunakan adalah penelitian evaluatif dengan metode analisis deskriptif. Peneliti menggunakan evaluasi dengan model CIPP (Context, Input, Process, and Product) yang dikembangkan oleh Stufflebeam pada tahun 1965. Teknik pengumpulan data yang digunakan peneliti adalah wawancara, observasi, dan dokumentasi. Instrumen yang digunakan peneliti adalah pedoman wawancara dan pedoman observasi. Pengujian keabsahan data dalam penelitian ini menggunakan proses trianggulasi teknik. Proses analisis data untuk menarik kesimpulan dalam penelitian ini menggunakan model Miles and Huberman.

\section{HASIL DAN PEMBAHASAN}

\section{Evaluasi Konteks Program Empat Bulan Lulus Iqra}

Evaluasi konteks program empat bulan lulus Iqra dianalisis dari beberapa aspek, diantaranya: tujuan program empat bulan lulus Iqra di SD Muhammadiyah Ambarketawang 3 Yogyakarta, Program empat bulan lulus Iqra sesuai dengan kebutuhan siswa.

a. Tujuan Program Empat Bulan Lulus Iqra di SD Muhammadiyah Ambarketawang 3 Yogyakarta.

Pada tahun ajaran 2015/2016 SD Muhammadiyah Ambarketawang 3 Yogyakarta menerapkan program empat bulan lulus Iqra dengan sasaran seluruh siswa kelas 1. Program ini dirancang dengan tujuan mempermudah siswa kelas 1 dalam penyesuaian ekstrakulikuler TPA yang akan diikuti mulai dari kelas 2 sampai kelas 6. Seluruh siswa kelas 1 yang sudah mampu menyelesaikan Iqra dalam waktu empat bulan akan dengan mudah mengikuti program TPA di kelas selanjutnya. Selain itu, program empat bulan lulus Iqra juga dirancang untuk merealisasikan visi dan misi yang dimiliki oleh sekolah, yaitu mengembangkan nilai-nilai agama Islam, Iman, dan taqwa kepada Allah SWT.

b. Program empat bulan lulus Iqra sesuai kebutuhan siswa.

Program percepatan belajar membaca Al Quran dengan metode Iqra didukung penuh oleh berbagai pihak, terutama ustaz dan ustazah pengampu program. Pengajaran secara intens dalam kelompok-kelompok kecil sangat mempermudah siswa dalam memahami setiap tahapan pada Iqra jilid 1 sampai jilid 6 . Ustaz dan 
ustazah juga menerapkan stategi pengajaran Iqra yang menyenangkan sehingga seluruh siswa merasa tertarik selama mengikuti pembelajaran. Penyampaian pengajaran Iqra di masing-masing kelompok dibuat menarik dan sesuai dengan tingkat perkembangan siswa kelas 1 sekolah dasar. Selain itu, ustaz dan ustazah juga menyampaikan materi pendukung lain seperti sirah nabi, doa sehari-hari, pengajaran akhidah dasar, dan materi-materi lain yang akan menunjang kemampuan pengetahuan pendidikan agama Islam bagi seluruh siswa.

\section{Evaluasi Input Program Empat Bulan Lulus Iqra}

Evaluasi input program empat bulan lulus Iqra dianalisis dari beberapa aspek, diantaranya:

a. Sumber daya manusia dalam pelaksanaan program empat bulan lulus Iqra.

Berdasarkan data terakhir tahun ajaran 2016/2017 terdapat 7 ustaz dan 5 uztazah pelaksana program empat bulan lulus Iqra yang mengampu sebanyak 71 siswa (data nama siswa terlampir). Dua belas ustaz tersebut dibagi dalam dua kelas, yaitu kelas 1 A dan kelas $1 \mathrm{~B}$. Masing-masing ustaz dibagi dalam kelompok kecil untuk mengampu 6 sampai 7 siswa pada masing-masing kelompoknya. Sistem pembagian kelompok siswa dilakukan oleh guru koordinator program.

b. Anggaran yang digunakan dalam pelaksanaan program empat bulan lulus Iqra.

Setiap periode tahun ajaran baru, sekolah mengestimasikan dana untuk program empat bulan lulus Iqra kurang lebih sebesar Rp 20.000.000,-. Sumber dana tersebut diperoleh dari keuangan sekolah serta orang tua siswa. Setiap orang tua siswa dianjurkan untuk memberikan sumbangan dana program sebesar $\mathrm{Rp}$ 4.000,--.per bulan.

Sarana dan prasarana yang diperlukan dalam pelaksanaan program empat bulan lulus Iqra Selama dua periode pelaksanaan pembelajaran Iqra, sekolah sudah cukup baik dalam menyediakan sarana dan prasarana untuk kelancaran pelaksanaan program. Peralatan atau media yang perlu digunakan untuk pembelajaran sudah tersedia. Salah satunya buku Iqra sebagai media utama dalam pembelajaran. Pengadaan Iqra dikelola oleh sekolah bekerjasama dengan AMM Kotagede Yogyakarta. Jumlah Iqra yang disediakan oleh sekolah sudah mencukupi untuk seluruh siswa.

Peralatan lain yang digunakan oleh ustaz adalah kartu prestasi siswa. Kartu prestasi dibuat untuk mengetahui progres pembelajaran Iqra bagi setiap siswa. Masing-masing ustaz membawa kartu prestasi selama proses pembelajaran Iqra berlangsung. Media lain yang juga disediakan oleh sekolah adalah buku kitaba. Buku kitaba disiapkan oleh sekolah dan dibagikan kepada masing-masing siswa. Buku ini digunakan siswa untuk menulis materi huruf hijaiyyah.

Fasilitas pendukung juga disediakan oleh sekolah demi kelancaran proses pembelajaran. Pada dasarnya, pembelajaran Iqra hanya dilaksanakan di ruang kelas, akan tetapi sekolah juga menyediakan tempat lain yang dapat digunakan sebagai lokasi pembelajaran. Hal ini dilakukan untuk meminimalisir munculnya rasa bosan siswa ketika pembelajaran Iqra di dalam ruang kelas. Ruangan lain yang dapat digunakan oleh ustaz misalnya, perpustakaan, laboratorium komputer, dan serambi masjid. Ruangan tersebut bebas digunakan oleh ustaz selama proses pembelajaran Iqra berlangsung.

c. Pedoman yang digunakan pada program empat bulan lulus Iqra.

Selama dua periode pelaksanaan program, ustaz belum menyiapkan silabus pembelajaran Iqra. Silabus belum dirancang oleh ustaz karena program empat bulan lulus Iqra masih dalam tahap percobaan. Saat ini ustaz belum menyiapkan 
silabus karena pembelajaran masih difokuskan pada membaca Iqra dan menulis huruf hijaiyyah saja. Sedangkan materi tambahan seperti bacaan sholat, hafalan surat pendek, kisah-kisah nabi, doa sehari-hari, dan lain sebagainya belum terlalu banyak disampaikan oleh ustaz.

Sebelum membuat rancangan silabus, pedoman yang digunakan ustaz dalam pembelajaran hanya bersumber dari buku Iqra saja. Silabus pengajaran Iqra baru akan disusun pada periode ketiga yaitu tahun ajaran 2017/ 2018. Ustaz merancang silabus yang berisi jadwal pemberian materi tambahan selain membaca Iqra dan menulis huruf hijaiyyah. Selain itu, dalam rancangan silabus yang dibuat juga terdapat rancangan media yang perlu digunakan ustaz dalam penyampaian materi. Silabus dapat digunakan oleh ustaz selama menjalankan program sehingga proses pengaj ran Iqra lebih terarah dan tidak terkesan monoton bagi siswa.

Pada dasarnya program empat bulan lulus Iqra hanya difokuskan pada materi pengajaran Iqra saja. Program hanya dibatasi pada materi membaca Iqra karena keterbatasan waktu yang digunakan. Selain itu, tuntutan ketercapaian keberhasilan program juga menyebabkan keterbatasan materi yang disampaikan oleh ustaz. Namun pada saat pelaksanaan di lapangan, ustaz tetap memberikan materi selain membaca Iqra sebagai materi penunjang. Hal ini dilakukan untuk menambah wawasan serta meminimalisir rasa bosan siswa ketika belajar membaca Iqra.

d. Metode pelaksanaan program empat bulan lulus Iqra.

Metode pertama yang dilakukan adalah melaksanakan penjajagan tingkatan Iqra. Seluruh ustaz dan guru melaksanakan tes membaca Iqra kepada masingmasing siswa untuk mengetahui kemampuan serta mengetahui pada jilid berapa siswa tersebut akan memulai belajar membaca Iqra. Tes penjajagan membaca Iqra ini dilaksankan di awal pelaksanaan program. Penjajagan ini dilakukan untuk mempermudah guru koordinator dalam menentukan pembagian kelompok siswa.

Hasil dari tes penjajagan digunakan guru koordinator sebagai salah satu acuan dalam membuat kelompok siswa. Seluruh siswa dibagi kedalam kelompokkelompok kecil dengan lima sampai tujuh siswa pada masing-masing kelompoknya. Pembagian kelompok ini ditentukan berdasarkan kriteria tingkatan jilid dan usia. Kelompok siswa yang telah terbentuk akan digunakan selama program empat bulan lulus Iqra berlangsung. Guru membagi siswa dalam kelompok kecil untuk mengintensifkan pengajaran Iqra serta mempermudah ustaz dalam mengelola siswa. Pembagian kelompok juga bertujuan untuk mempermudah guru koordinator dalam memantau ketercapaian dan peningkatan kemampuan membaca Iqra pada masing-masing siswa.

\section{Evaluasi Proses Program Empat Bulan Lulus Iqra}

a. Faktor pendukung pelaksanaan program empat bulan lulus Iqra

Terdapat beberapa faktor yang mendukung selama pelaksanaan program empat bulan lulus Iqra di SD Muhammadiyah Ambarketawang 3 Yogyakarta, yaitu siswa atau peserta didik, kepala sekolah, guru dan ustaz pelaksana program, fasilitas pembelajaran, dana program.

b. Faktor penghambat pelaksanaan program empat bulan lulus Iqra.

Penghambat pelaksanaan program empat bulan lulus Iqra di SD Muhammadiyah Ambarketawang 3 Yogyakarta adalah kurangnya partisipasi orang tua dalam mendukung siswa untuk membaca Iqra ketika di rumah. Pada dasarnnya upaya meningkatkan kemampuan membaca Iqra anak akan berhasil apabila orang tua juga berperan aktif dalam mengingatkan siswa untuk membaca Iqra. Usaha untuk mengajarkan anak dapat membaca Iqra dengan lancar seharusnya juga dilakukan 
oleh orang tua. Kondisi saat ini, tidak sedikit orang tua yang terlalu sibuk dengan pekerjaan sehingga kewajiban orang tua untuk mengingatkan anak belajar membaca Iqra menjadi terlupakan. Hal ini yang menjadi salah satu penghambat dalam kesuksesan program membaca Iqra bagi siswa.

\section{Evaluasi Produk Program Empat Bulan Lulus Iqra}

a. Mencapai kriteria keberhasilan lulus Iqra

Pada periode pertama tahun ajaran 2015/ 2016 prosentase keberhasilan lulus Iqra siswa mencapai $75 \%$. Kemudian pada periode kedua tahun ajaran 2016/ 2017 keberhasilan lulus Iqra mencapai $50 \%$. Dari hasil prosentasi tersebut maka dapat disimpulkan bahwa empat bulan lulus Iqra menjadi program yang berhasil dilaksanakan oleh SD Muhammadiyah Ambarketawang 3 Yogyakarta.

b. Meningkatnya jumlah keberhasilan lulus Iqra

Apabila dianalisis dari dua periode pelaksanaan, saat ini belum terdapat peningkatan jumlah keberhasilan program. Dari data yang ditemukan terdapat penurunan prosentasi lulus Iqra siswa. Periode pertama dengan prosentasi $75 \%$ menurun menjadi $50 \%$ keberhasilan lulus Iqra pada periode kedua. Penurunan jumlah keberhasilan lulus Iqra dipengaruhi berbagai faktor, salah satunya adalah peningkatan jumlah siswa pada periode ke dua.

c. Antusias siswa terhadap program empat bulan lulus Iqra

Selama proses pembelajaran Iqra, siswa sangat aktif dalam mengikuti materi yang dismpaikan oleh ustaz. Pembelajaran disampaikan dengan menyenangkan oleh ustaz sehingga siswa merasa nyaman dan tertarik ketika pembelajaran berlangsung. Setiap siswa antusias untuk membaca Iqra pada masing-masing kelompoknya. Antusias siswa terhadap pembelajaran juga dapat dilihat ketika ustaz menyampaikan materi tambahan seperti menulis huruf hijaiyyah, hafalan surat dan doa sehari-hari. Penyelenggaraan program empat bulan lulus Iqra juga menjadi metode khusus untuk menciptakan anak gemar belejar membaca Iqra.

\section{SIMPULAN}

Berdasarkan hasil penelitian dan pembahasan mengenai evaluasi program empat bulan lulus Iqra jilid 1 sampai jilid 6 di SD Muhammadiyah Ambarketawang 3 Yogyakarta dengan metode CIPP, maka peneliti dapat menyimpulkan sebagai berikut: Program empat bulan lulus Iqra di SD Muhammadiyah Ambarketawang 3 Yogyakarta sesuai dengan kebutuhan siswa. Seluruh siswa kelas 1 akan mampu menguasai Iqra dalam kurun waktu yang singkat sehingga mempermudah dalam penyesuaian program TPA yang akan dilaksanakan di kelas selanjutnya. Program juga bertujuan untuk merealisasikan visi, misi, dan tujuan yang dibuat oleh sekolah. Faktor pendukung pelaksanaan program diantaranya siswa, kepala sekolah, guru, dan ustaz, fasilitas pembelajaran (ruang perpustakaan, mushola, lab komputer), dan dana program yang digunakan. Faktor penghambat pelaksanaan program empat bulan lulus Iqra yaitu kurangnya partisipasi orang tua dalam mengingatkan anak membaca Iqra ketika di rumah, serta perbedaan kemampuan yang dimiliki masing-masing anak

Prosentasi keberhasilan lulus Iqra tahun ajaran 2015/ 2016 mencapai $75 \%$ dan pada tahun ajaran 2016/ 2017 mencapai $50 \%$. Hasil evaluasi produk menunjukkan tidak ada kenaikan prosentase keberhasilan lulus Iqra selama dua periode. Namun dengan penyelenggaraan program tersebut dapat menciptakan anak yang gemar belajar Iqra setiap hari. Sehingga program empat bulan lulus Iqra sebaiknya tetap dilaksanakan dengan melakukan perbaikan dibeberapa komponen program. 


\section{DAFTAR PUSTAKA}

Arikunto, S. (2009). Evaluasi Program Pendidikan. Jakarta: Bumi Aksara

Arikunto, S. (2013). Prosedur Penelitian Suatu Pendekatan Pratik. Jakarta: Rineka Cipta.

Budiyanto, H. M. (1995). Prinsip-Prinsip Metodologi Buku Iqro`Cara Cepat Belajar Membaca Al Qur`an. Yogyakarta: Team Tadarus AMM.

Moleong, L. J. (2013). Metode Penelitian Kualitatif. Bandung: Remaja Rosdakarya.

Muhaimin. (2010). Arah Baru Pengembangan Pendidikan Islam pemberdayaan, Pengembangan Kurikulum hingga Redefinisi Islamisasi Pengetahuan. Bandung: Nuansa.

Nata, A. (2010). Manajemen Pendidikan Mengatasi Kelemahan Pendidikan Islam di Indonesia. Jakarta: Kencana Prenada Media Group.

Sudrajat, A. (2013). Din Al-Islam. Yogyakarta: UNY Press

Sugiyono. (2011). Metode Penelitian Pendidikan Pendekatan Kuantitatif, Kualitatif, dan $R \& D$. Bandung: Alfabeta.

Sugiyono. (2015). Metode Penelitian Pendidikan Pendekatan Kuantitatif, Kualitatif, dan $R \& D$. Bandung: Alfabeta.

Sundari, R. (2008). Evaluasi Pemanfaatan Laboratorium Dalam Pembelajaran Biologi Di Madrasah Aliyah Negeri. Jurnal Penelitian dan Evaluasi Pendidikan, 7 -14. Diakses di http://journal.uny.ac.id/ index.php/ jpep/ article/ view/1427/1215 pada 29 Desember 2016

Wardoyo, H. E. (2016). Penerapan Metode Pembelajaran Baca Tulis Al Qur'an Pada Siswa. Sumbula, 11. Diakses di http://ejournal.kopertais4.or.id/ index.php/irfani/article/view/2333/1735 pada 29 Desember 2016

Widoyoko, E. P. (2010). Evaluasi Program Pembelajaran. Yogyakarta: Pustaka Pelajar.

UNY, T. T. (2014). Tutorial PAI UNY. Yogyakarta: Tim Tutorial Pendidikan Agama Islam 